\title{
Ethnologies
}

\section{Whistling Banjoman: George Hector. By Anne Fawcett. (Gagetown: Otnabog Editions, 1999. Pp 124, ISBN 0-9685999-0-7, plok.)}

\section{Gillian Turnbull}

Volume 25, numéro 2, 2003

Language and Culture / Langue et culture

URI : https://id.erudit.org/iderudit/008062ar

DOI : https://doi.org/10.7202/008062ar

Aller au sommaire du numéro

Éditeur(s)

Association Canadienne d'Ethnologie et de Folklore

ISSN

1481-5974 (imprimé)

1708-0401 (numérique)

Découvrir la revue

Citer ce compte rendu

Turnbull, G. (2003). Compte rendu de [Whistling Banjoman: George Hector.

By Anne Fawcett. (Gagetown: Otnabog Editions, 1999. Pp 124, ISBN

0-9685999-0-7, pbk.)]. Ethnologies, 25(2), 255-258.

https://doi.org/10.7202/008062ar

Ce document est protégé par la loi sur le droit d'auteur. L'utilisation des services d'Érudit (y compris la reproduction) est assujettie à sa politique d'utilisation que vous pouvez consulter en ligne.

https://apropos.erudit.org/fr/usagers/politique-dutilisation/ 
A giant woman was walking around at sunrise when the red heads in the border started making fun of her. She told them, "Don't make fun of me, I have power to do anything." The faces on her legs started shouting at the red heads. When her arms and legs turned into birds, these birds told the giant she could only escape by flying (94-95).

At this point we are nicely caught between myth, vision or dream and personal history. Avaalaaqiaq does not suggest that this is a traditional story, and it is dangerously tempting to imagine it as a reflection upon projected doubt of herself and her art. But what is essential is the giant woman's response "I have power to do anything."

For folklorists, the book offers a varied feast. As a teaching as well as personal resource, it informs issues such as adaptation, cultural perception and cross-cultural communication, social history, indigenous autobiography, state/indigenous relations, and the provocative movement of expression between narrative and graphic media. I have suggested that the mode of expression is also significant for cross-cultural psychological study. The title thesis, adequately justified by the content, raises obvious metaphysical issues of perception and statement. Nasby and Avaalaaqiaq have together given us a book that informs on many levels while beguiling the mind with images that rise from very deep places. For me, this is its great virtue, to introduce us again to language and stories of Inuit perception, and thus to remind us that we need all the ways of knowing.

\section{Reference}

Swinton, George. 1965. Eskimo Sculpture. Toronto, MacLelland \& Stewart.

F. Mark Mealing

Kaslo, British Columbia

Whistling Banjoman: George Hector. By Anne Fawcett. (Gagetown: Otnabog Editions, 1999. Pp 124, ISBN 0-9685999-0-7, pbk.)

Anne Fawcett's biography of George Hector is a story that tells us of one of New Brunswick's most well-known and respected country musicians of the twentieth century. A local musician who was influential in developing the country music scene of the East Coast, Hector is celebrated for his work in community events, radio, and later television. 
He began his career by playing local barn dances as a part-time hobby for very little money, and became a neighbourhood favourite. His ubiquitous presence at such events inevitably led to bigger opportunities, such as the Don Messer Radio Show in 1934 and his own Maritime Farmer Barn Dance show on CHSJ that started in 1938 and went for twenty years. Eventually, the Maritime Farmers moved to local television and maintained their popular show for another six years. Hector has since remained an prominent figure in New Brunswick country music; he continues his struggle to keep the square dance tradition alive in the community, and has been inducted into the New Brunswick Country Music Hall of Fame and has received the ECMA's Stompin' Tom Award. Fawcett's book tells the story of his childhood in Gagetown, his multifaceted career, and his contribution to the music of Eastern Canada.

The book is told entirely in Hector's own voice, with sections of interviews spliced together to create a chronology of his life. The first section of the book, "Home", is a brief history of Hector's family, his home life, and his education. Hector was born in 1911 to LeBaron Hector and Jessie Haines and the only boy in a family of five children. Jessie Haines had descended from Jim Haines and Annie Wright; Annie Wright was the child of a white Irish woman (Jane Owens) and an African-Canadian man (Charles Wright). The Wrights and the Haines families lived on settlements granted to the slaves in New Brunswick, and George grew up among a mixed population in Gagetown. His parents were both singers and encouraged George's musical development. His father worked numerous jobs, from sawing ice and driving cattle to working as a deckhand and farming.

George followed in LeBaron's footsteps, working several varied jobs throughout his life. The second section, "Work", details these occupations. George worked with his father operating the Gagetown cable ferry; he delivered refrigerators and washing machines by horse and sled; he built fireplaces; he worked for the CPR; and he was a chauffeur for Howard Robinson (director of the Royal Bank and CPR among other things) for a decade.

However, the final section, "Music", demonstrates that in spite of his day jobs, Hector was a dedicated musician who used every minute of his spare time to spread music throughout the community. This section of the book examines the people he played with in local dance 
bands and the Maritime Farmers; the significant musicians and local celebrities, such as Don Messer, that he encountered in his gigs; and the fleeting commitment of radio and television in the latter period of his career. His disappointment with the lack of respect as a band leader he faced because of his racial background is evident throughout, despite the widespread celebration of his playing. Hector also seems to regret that he did not follow through with music as a full-time job and that he did not spend more time on his musical growth and progress. Finally, he is disappointed with the struggle it took to maintain the tradition of country music and barn dances in New Brunswick despite their waning popularity.

There are several assets to Fawcett's biography of Hector. The appendices of his community recognition and awards and his discography provide an inkling of his effect in the local music scene, while the endnotes are extremely helpful in deciphering certain confusing and vague sections of his stories. The photographs are a welcome tool in visualizing Hector's life and the surrounding New Brunswick region, and the sidebar short tales interspersed throughout the book are entertaining. These tales endow the book with a light, humorous quality, and help in creating a more personal connection between Hector and the reader. Finally, the great asset of the book is that it is told in Hector's own voice.

However, the book's greatest asset is also its greatest downfall. While Hector's voice provides an authentic appeal to readers, it lacks a mediating voice that is much needed at certain points. Fawcett's voice is completely nonexistent aside from her acknowledgments. While the subject's voice is without a doubt essential in a book such as this, there is no accompanying interpretation. It is presented as a biography, but its lack of an outside voice turns the book into more of an autobiography. The result of the absence of an external storyteller is that the book is often disjointed and stories are not connected; certain people move in and out of tales without introduction or background, and seemingly important events are only mentioned in passing. It would be helpful at times to have a framework from the author to situate the story more firmly. I believe a combination of extended quotes from Hector and detailed interpretation and context from Fawcett would have improved the book. 
Overall, if one is looking for an entertaining story of an influential figure in East Coast country music, this is a good book. Hector's vocal presence throughout makes personal memories and stories much more effective than they would be as told from a distance. Fawcett clearly went in-depth with her interviews and research and pieced the information together in a way that is readable and is an all-round history of Hector. While it would have been beneficial to have a more structured context from Fawcett, as well as some analysis from an author who is very involved with the man, his music, and the community, it is a good start for those who want to learn more about George Hector and country music in New-Brunswick.

Gillian Turnbull University of Alberta

Edmonton

Spirit Wrestlers Voices: Doukhobor Pioneers' Strategies for Living. By Koozma Tarasoff. (Legas Publishing, Ottawa, 2002. Pp. xvi + 480, illustr. photographs, graphics, diagrams, maps, ISBN 1-896031-12-9, hardcover. CD-ROM to accompany, but not available at time of review.)

Forty years ago, Koozma Tarasoff published a three-volume study, In Search of Brotherhood. This is not a well-known work; it was a mimeographed samizdat in an edition of ten copies. In 1969, he wrote A Pictorial History of the Doukhobors; in 1977, for the then National Museum of Man, he wrote Traditional Doukhobor Folkways: An Ethnographic and Biographic Record of Prescribed Behaviour; and in 1982, Plakun Trava - The Doukhobors. He has also written and edited a great range of other materials in the field of Doukhobor Studies.

There is a cliché in Academe: all scholars have only one book, which starts with their dissertations and repeats the same ideas forever. Of course there is an element of truth in this, although it has at least two heads. The second head is a small one some scholars are incapable of advancing beyond their initial insight. But the great first head is the depth of knowledge a wise scholar will choose about an inexhaustible subject. I choose to consider Tarasoff to be a wise scholar. Early in his career he responded to the life of his own tradition as a critic and 